\title{
HUBUNGAN ANTARA BEBAN KERJA MENTAL DENGAN STRES KERJA PADA MASINIS UPT CREW KA BLITAR DAOP VII MADIUN PT. KERETA API INDONESIA
}

\author{
Kiki Astrea Trisminingsih \\ Fakultas Kesehatan Masyarakat, Universitas Airlangga \\ Email: kikiastrea@gmail.com
}

\begin{abstract}
Machinist is an example of work that uses both mental and physical aspect. The potential of machinist experiencing work stress also depends on the workload borne. The purpose of this study was to analyze the relationships of the mental workload with work stress. The population of this study was all the UPT Crew VII Operational Area Madiun, PT. Kereta Api Indonesia (Persero), which is as many as 24 machinists. The number of samples taken from the entire population. The dependent variable in this study was a mental workload and the independent variable was work stress. Based on the research, it can be concluded that the majority of machinists (58.3\%) have a heavy mental workload, and 75\% of machinists experience high levels of work stress. From the statistical test obtained the value of the contingency coefficient is 0.683 , so it can be concluded that there is a strong relationship between mental workload and work stress on machinists UPT Crew Blitar Railway VII Operational Area Madiun PT. Kereta Api Indonesia (Persero).
\end{abstract}

Keywords: Mental Workload, Work Stress, Machinist

\begin{abstract}
ABSTRAK
Salah satu contoh pekerjaan yang banyak menggunakan aspek mental daripada aspek fisik adalah pekerjaan seorang masinis. Semakin berat beban kerja yang ditanggung maka akan semakin besar pula risiko masinis mengalami stres kerja. Tujuan dari penelitian ini adalah menganalisis tentang hubungan beban kerja mental dengan stres kerja. Populasi dalam penelitian ini adalah seluruh masinis yang ada di UPT Crew KA Blitar DAOP VII Madiun PT. Kereta Api Indonesia (Persero) yaitu sebanyak 24 masinis. Jumlah sampel penelitian diambil dari seluruh jumlah populasi yang ada. Variabel dependen pada penelitian ini adalah beban kerja mental dan varibel independennya adalah stres kerja. Berdasarkan penelitian dapat disimpulkan sebagian besar yaitu 58,3\% masinis memiliki beban kerja mental berat, stres kerja diperoleh hasil sebagian besar 75\% masinis mengalami stres kerja tingkat tinggi. Dari uji statistik diperoleh nilai koefisien kontingensi yaitu 0,683 sehingga disimpulkan kuat hubungan antara beban kerja mental dengan stres kerja pada masinis UPT Crew KA Blitar DAOP VII Madiun PT. Kereta Api Indonesia (Persero) termasuk dalam kuat hubungan kategori kuat.
\end{abstract}

Kata kunci: Beban Kerja Mental, Stres Kerja, Masinis 


\section{PENDAHULUAN}

Perkembangan yang sangat pesat saat ini salah satunya adalah transportasi. Perkembangan penduduk saat ini merupakan salah satu pemicu pentingnya transportasi. Permasalahan penduduk akan pentingnya kebutuhan transportasi dapat diatasi salah satunya dengan menggunakan sarana kereta api. ${ }^{1}$ Kereta api merupakan sarana transportasi darat yang dapat menampung menumpang dalam skala yang besar, namun hingga saat ini masih kerap terjadi kecelakaan kereta api. Beberapa jenis kecelakaan yang terjadi pada kereta api seperti tabrakan dengan kendaraan umum lain, kereta api anjlok dan kereta api terguling.

Kecelakaan yang terjadi dapat dipengaruhi oleh beberapa faktor seperti sarana prasarana pada kereta api, faktor alam dan faktor sumberdaya manusianya sendiri. ${ }^{2}$ Kementerian Perhubungan Republik Indonesia menyebutkan kecelakaan kereta api yang disebabkan oleh human error sebesar $24 \%$. Human error yang terjadi pada masinis seperti melanggar kecepatan atau tidak mengikuti standar operasi dapat dipengaruhi oleh kurangnya konsentrasi masinis dalam mengerjakan pekerjaannya. ${ }^{3}$

Baik buruknya kinerja dan keselamatan operasional perkeretaapian tidak lepas dari pentingnya peran seorang masinis. ${ }^{4}$ Menurut Peraturan Menteri Perhubungan Republik Indonesia Nomor PM 4 tahun 2017 tentang Sertifikasi Kecakapan Awak Sarana Perkereta- apian Bab II tentang Pengoperasian Sarana Perkeretaapian Pasal 2 awak sarana perkeretaapian (masinis) harus memiliki sertifikat kecakapan untuk mengoperasikan sarana perkeretaapian yang dikeluarkan oleh Direktur Jenderal.

Tanggung jawab utama masinis adalah menjamin keselamatan semua yang ada di dalam rangkaian kereta api dan mengusahakan ketepatan waktu dalam perjalanannya seperti memberangkatkan, memberhentikan lokomotif beserta rangkaiannya kereta yang ditarik dan mengatur kecepatan kereta. Salah satu contoh pekerjaan yang banyak menggunakan aspek mental daripada aspek fisik adalah pekerjaan seorang masinis. Konsentrasi dan tingkat fokus yang tinggi dibutuhkan oleh masinis pada saat melakukan dinasan. ${ }^{2}$

Beban kerja mental menurut Manuaba adalah kebutuhan mental seseorang untuk melakukan pekerjaan seperti berfikir, menghitung dan memperkirakan sesuatu. ${ }^{5}$ Beban kerja mental yang dialami masinis dapat berupa tanggungjawab atas keselamatan, keamanan serta menjamin kenyamanan penumpangnya.

Semakin berat beban kerja yang ditanggung maka akan semakin besar pula risiko masinis mengalami stres kerja. Stres kerja adalah suatu kondisi fisik dan emosional yang berbahaya yang terjadi ketika pekerjaan yang dilakukan tidak sesuai dengan kemampuan, sumber daya dan kebutuhan pekerja. ${ }^{6}$ 
Tujuan dari penelitian ini adalah menganalisis tentang hubungan beban kerja mental dengan stres kerja masinis UPT Crew Kereta Api Blitar Daerah Operasional VII Madiun PT. Kereta Api Indonesia (Persero).

\section{METODE PENELITIAN}

Penelitian ini menggunakan pendekatan penelitian kuantitatif dengan menggunakan metode analitik observasional cross sectional. Pada penelitian ini peneliti akan meneliti hubungan antara beban kerja mental dengan stres kerja pada masinis UPT Crew KA Blitar DAOP VII Madiun PT. Kereta Api Indonesia (Persero) dalam satu waktu. Penelitian ini dilakukan di Kantor UPT Crew KA Blitar DAOP VII Madiun pada bulan September sampai Oktober 2018.

Populasi dalam penelitian ini adalah seluruh masinis yang ada di UPT Crew KA Blitar DAOP VII Madiun PT. Kereta Api Indonesia (Persero) yaitu sebanyak 24 masinis. Sampel peneltian dengan menggunakan total sampling yaitu seluruh jumlah populasi dijadikan sebagai sampel.

Variabel independen penelitian ini adalah beban kerja mental sedangkan variabel dependennya adalah stres kerja. Data primer didapatkan dengan menggunakan tehnik kuesioner. Kuesioner stres kerja diambil dari kuesioner HSE 2003, kuesioner beban kerja mental menggunakan kuesioner NASA TLX yang telah dilakukan uji validitas dan reliabilitas. Data yang telah didapatkan kemudian diolah melalui proses editing, pemberian skor (scoring) dan tabulasi. Kemudian diinput dalam software/aplikasi computer untuk proses pengujian statistik. Teknik penyajian data penelitian ini dalam bentuk teks, tabel frekuensi, dan tabulasi silang. Untuk mengetahui kuat hubungan antar variabel menggunakan nilai koefisien kontingensi correlation spearman.

\section{HASIL DAN PEMBAHASAN}

\section{Hasil Penelitian}

Hasil dari penelitian yang telah dilakukan menunjukkan beban kerja mental dan stres kerja pada masinis UPT Crew KA Blitar DAOP VII Madiun PT. Kereta Api Indonesi (Persero), sebagai berikut:

\section{Beban Kerja Mental}

Tabel 1. Beban Kerja Mental masinis UPT Crew KA Blitar DAOP VII Madiun PT. Kereta Api Indonesia (Persero).

\begin{tabular}{lcc}
\hline Beban Kerja Mental & Frekuensi & Persentase \\
\hline Sedang & 10 & 41,70 \\
\hline Berat & 14 & 58,30 \\
\hline Total & 24 & 100,00 \\
\hline
\end{tabular}

Berdasarkan Tabel 1 dapat dilihat bahwa sebagian besar masinis UPT Crew KA Blitar DAOP VII Madiun PT. Kereta Api Indonesia (Persero) memiliki beban kerja mental berat atau sebanyak 58,3\% masinis, sedangkan yang memiliki beban kerja mental sedang sebanyak $41,7 \%$ masinis. 


\section{Stres Kerja}

Tabel 2. Stres Kerja masinis UPT Crew KA Blitar DAOP VII Madiun PT. Kereta Api Indonesia (Persero)

\begin{tabular}{lrr}
\hline Stres Kerja & Frekuensi & Persentase \\
\hline Sedang & 6 & 25,00 \\
\hline Tinggi & 18 & 75,00 \\
\hline Total & 24 & 100,00 \\
\hline
\end{tabular}

Berdasarkan Tabel 2 dapat dilihat bahwa sebagian besar masinis UPT Crew KA Blitar DAOP VII Madiun PT. Kereta Api Indonesia (Persero) mengalami tingkat stres kerja tingkat tinggi yaitu sebanyak $75 \%$ masinis, sedangkan masinis yang mengalami stres kerja tingkat sedang ada $25 \%$.

\section{Hubungan antara Beban Kerja Mental dengan Stres Kerja}

Tabel 3. Hubungan antara Beban Kerja Mental dengan Stres Kerja pada masinis UPT Crew KA Blitar DAOP VII Madiun PT. Kereta Api Indonesia (Persero).

\begin{tabular}{|c|c|c|c|c|c|c|c|}
\hline \multirow[t]{3}{*}{ Beban Kerja Mental } & \multicolumn{4}{|c|}{ Stres Kerja } & \multirow{2}{*}{\multicolumn{2}{|c|}{ Total }} & \multirow[t]{2}{*}{$\mathrm{r}$} \\
\hline & \multicolumn{2}{|c|}{ Sedang } & \multicolumn{2}{|c|}{ Tinggi } & & & \\
\hline & $\mathrm{N}$ & $\%$ & $\mathrm{~N}$ & $\%$ & $\mathrm{~N}$ & $\%$ & \\
\hline Sedang & 6 & 100,00 & 0 & 0,00 & 6 & 100,00 & \\
\hline Tinggi & 4 & 22,20 & 14 & 77,80 & 18 & 100,00 & 0,683 \\
\hline Total & 10 & 41,70 & 14 & 58,30 & 24 & 100,00 & \\
\hline
\end{tabular}

Berdasarkan Tabel 3. dapat diketahui bahwa sebagian besar $(77,8 \%)$ masinis yang memiliki beban kerja mental berat mengalami kelelahan kerja tingkat tinggi. Berdasarkan uji statistik diperoleh coefficient correlation sebesar 0,683. Menurut Sugiyono nilai coefficient correlation tersebut ada dalam rentang nilai 0,60-0,799 yang artinya kuat hubungan antar varibelnya termasuk dalam kategori kuat. $^{7}$

\section{Pembahasan}

Beban kerja mental berisiko menjadi salah satu penyebab stres ditempat kerja. Bekerja dibawah tekanan waktu untuk mencapai target adalah sumber stres yang sering terjadi di tempat kerja. Penurunan produktivitas kerja atau penyebab dari Penyakit
Akibat Kerja dikarenakan beban pekerjaan yang tinggi sehingga melebihi kapasitas kerja. ${ }^{8}$ Perhitungan beban kerja di perusahaan sangat penting dilakukan. Beban kerja bergantung pada tuntutan atau intensitas penugasan kerja, hal ini dapat menjadi salah satu sumber stres bagi pekerja. ${ }^{9}$ Selaras dengan Chen dkk., yang menyebutkan bahwa beban kerja yang berat yang dialami dalam jangka panjang dapat berpengaruh pada kesehatan tenaga kerja secara fisik dan mental, sehingga respon dari situasi di sekitar tempat kerja dapat berbahaya menjadi ancaman seperti ketakutan, cemas, merasa bersalah, marah, sedih, putus asa dan stres. ${ }^{10}$

Hasil uji statistik kuat hubungan antara beban kerja mental dengan stres kerja pada masinis UPT Crew KA Blitar DAOP VII 
Madiun mendapatkan nilai koefisien kontingensi 0,683 yang artinya kuat hubungan antara variabel tersebut termasuk kategori kuat. Penelitian yang dilakukan oleh Shah dkk., hasilnya menyebutkan beban kerja memiliki hubungan yang signifikan terhadap performa pekerja. ${ }^{9}$ Kemampuan pekerja dapat memengaruhi terjadinya beban kerja yang tinggi. Prabawati dalam penelitiannya mengatakan beban kerja mental memiliki hubungan dengan kejadian stres, penelitian yang dilakukan pada perawat di Rumah Sakit mendapatkan hasil $\mathrm{p}=$ 0,027 yang artinya ada hubungan signifikan antara kedua variabel dengan nilai kuat hubungan korelasi 0,556 yang berarti hubungan antar variabel kuat. ${ }^{11}$ Serupa dengan Hasil penelitian Kusnadi tentang Hubungan antara Beban Kerja dan Self-Efficacy dengan Stres kerja pada Dosen Universitas X mengemukakan bahwa ada nilai yang signifikan antara korelasi 0,782>0,3 yang artinya ada hubungan antara beban kerja dengan stres kerja. ${ }^{12}$

Ashfort mengatakan beban kerja adalah penyebab stres yang signifikan yang memunculkan respon psikologi yang merusak dan menumbuhkan gejala kelelahan. Ketika dalam perjalanan tidak jarang masinis dihadapkan dengan kesulitan dijalan diantara-nya harus peka terhadap lokomotif dan rangkaian yang dibawanya, berkonsentrasi dan waspada terhadap medan atau lintasan yang dilalui, sigap dalam melakukan tunjuk sebut setiap melihat semboyan atau marka. Saat terjadi kerusakan lokomotif di jalan bebas, masinis harus mampu memutuskan akan tetap berjalan atau berhenti meminta pertolongan dengan risiko akan menggangu perjalanan seperti ketepatan waktu kedatangan kereta api, jika terjadi suatu kecelakaan masinis harus siap bertanggungjawab dengan melaporkan kronologis kejadian kepada pihak-pihak yang menangani perihal kecelakaan tersebut. Masinis adalah pemimpin perjalanan kereta api yang bertanggungjawab penuh atas keselamatan dan kenyamanan penumpangnya. Tuntutan pekerjaan tersebut menyebabkan tingginya nilai beban kerja mental masinis sehingga masuk dalam kategori beban kerja mental berat. Stres kerja merupakan salah satu dampak buruk dari beban kerja mental.

\section{SIMPULAN DAN SARAN}

\section{Simpulan}

Kesimpulan dari penelitian ini adalah sebagain besar yaitu 58,3\% masinis UPT Crew KA Blitar DAOP VII Madiun PT. Kereta Api Indonesia (Persero) memiliki beban kerja mental berat. Dari penelitian stres kerja diperoleh hasil sebagian besar 75\% masinis mengalami stres kerja tingkat tinggi. Hasil uji statistik menunjukkan nilai koefisien kontingensi yaitu 0,683 sehingga disimpulkan ada hubungan yang kuat antara beban kerja mental dengan stres kerja pada masinis UPT Crew KA Blitar DAOP VII Madiun PT. Kereta Api Indonesia (Persero). 


\section{Saran}

Sebaiknya masinis melakukan peregangan otot sebelum berdinas atau disela-sela pekerjaannya seperti menggerakkan kaki dan tangan sehingga aliran darah pada tubuh tetap lancar, ketegangan otot menjadi rileks dan menjadikan pikiran lebih tenang. Masinis harus dapat mempergunakan waktu istirahat dengan baik agar saat melanjutkan pekerjaannya beban dari pekerjaan sebelumnya berkurang serta mengurangi stres kerja yang dirasakan.

Bagi perusahaan memberikan sosialisasi mengenai beban kerja mental serta stres kerja sehingga masinis dapat mengerti dampak dari beban kerja mental dan stres kerja dan paham bagaimana cara mengatasinya. Perusahaan mengadakan program trevelling bersama sebagai salah satu usaha penyegaran untuk masinis.

\section{REFERENSI}

1. Pramasari, A. L., Widjasena, B., Kurniawan, B., \& Suroto. Analisis Tingkat Risiko Kelelahan Pada Masinis Comuter Line Rute Bogor-Jakarta Kota. jurnal Kesehatan Masyarakat. 2017.

2. Astuty, S. M., Caecillia, \& Yuniar. Tingkat Beban Kerja Mental Masinis Berdasarkan NASA-TLX (Task Load Index) di PT. KAI DAOP II Bandung. Jurnal Online Institut Teknologi Nasional. 2013.

3. Peraturan Menteri Perhubungan Nomor PM 4 Tahun 2017 tentang Sertifikasi Kecakapan Awak Sarana Perkeretaapian.

4. Sinaga, R. M., \& Erwandi, D. Gambaran Stres Kerja Pada Masinis Jurusan Luar Kota PT Kereta Api Indonesia di Stasiun jatinegara. 2014.
5. Tarwaka. Ergonomi Industri atau Dasar Dasar Pengetahuan Ergonomi dan Aplikasi di Tempat Kerja. Surakarta: Harapan Press. 2013.

6. Dewi. Hubungan antara Beban Kerja Mental dengan stres Kerja pada Dosen di Universitas Jember. Artikel Ilmiah Hasil Penelitian Mahasiswa. 2016.

7. Sugiyono. Metode Penelitian Kuantitatif Kualitatif . Bandung: Alfabeta. 2012.

8. Pertiwi. Hubungan antara Beban Kerja Mental dengan stres Kerja pada Dosen di Suatu Fakultas. Jurnal Kesehatan Masyarakat. (e-Journal). 2017. Volume 5, Nomor 3, Juli 2017 (ISSN: 2356-3346) http://ejournals1.undip.ac.id/index.php/jkm

9. Shah, S.S.h., Jaffari, A. R., Aziz, j., Ejaz, W., U1-Haq, I., \& Raza, S.N. Workload and Performance of Employees. Interdiciplinary Journal of Contemporary Research in Business. 2011. 3(5): 256-267.

10. Chen, T.H., Wu, K.H., Lin, W.J., Horna, W.I., and Shied, C.J. Incorporating Workload and Performance Levels into Work Situation Analysis of Employees with Application to a Taiwanese Hotel Chain. American Journal of Applied Sciences. 2010. 7(5) 692-697.

11. Prabawati, R. Hubungan Beban Kerja Mental dengan Stres Program Studi Diploma IV Keselamatan dan Kesehatan Kerja Pada Perawat bagian Rawat Inap RSJD Dr. R. Soedjarwadi Klaten. Skripsi. Semarang: Universitas Negeri Semarang. 2012.

12. Kusnadi, M.A. Hubungan antara Beban Kerja dan Self Efficiacy dengan Stres Kerja pada Dosen Universitas X. Surabaya: Jurnal Ilmiah Mahasiswa Universitas Surabaya 2014. Vol 3 No 1. 